\title{
GEOPOLITICS AND OCCUPATION OF THE
} MEDITERRANEAN SEA

\section{Azka MADIHAH*}

\begin{abstract}
The Mediterranean Sea is often forgotten in the context of the current occupation in Bayt al-Maqdis, which includes a small part of the Eastern Mediterranean Sea. Indeed, apart from occupation of the land, Bayt al-Maqdis also faces occupation of its sea. According to El-Awaisi's Barakah Circle Theory, world peace will only be established if peace is present in Bayt al-Maqdis. Accordingly, a comprehensive view of peace establishment efforts in Bayt al-Maqdis will be pursued. To achieve this liberation of Bayt al-Maqdis from the occupation of its land, sea, natural resources, energy, and culture requires knowledge of the Mediterranean Sea. The liberation of Bayt al-Maqdis should include the liberation of the Mediterranean, since the real point of sea power is not so much what happens at sea, but how those actions influence events on land. Thus, Muslim countries, and especially Turkey as the strongest state on the Mediterranean Sea's coast, should be aware of the potential and threat that accompanies the establishment of peace in Bayt al-Maqdis. This article uses a qualitative approach to investigate the case study of geopolitics and occupation in the Mediterranean Sea based on the Bayt al-Maqdis Barakah Circle Theory. This study has shown that, at present, entwined military, political, and economic interests from coastal countries and international superpowers of the Mediterranean Sea should be the focus for Muslim countries in liberating Bayt al-Maqdis. This is because without liberating this specific part of Bayt al-Maqdis, the current occupation will be difficult to end.
\end{abstract}

KEYWORDS: Bayt al-Maqdis, Mediterranean Sea, geopolitics, occupation.

\section{INTRODUCTION}

Bayt al-Maqdis, as a strategic region in the middle of the Asian, European, and African continents, has a rich and well-established history - having witnessed numerous nations, cultures, and civilisations (El-Awaisi, 2007). The region also includes a small part of the Eastern Mediterranean Sea (map on figure 1). Historically, this sea has also witnessed more war and conflict than any other sea in the world (Stavridis, 2018). Despite the importance of Bayt al-Maqdis and its geopolitical context, there has been little discussion about its role regarding nearby seas, such as the Mediterranean, Red, and Black Seas. One might argue that the Eastern Mediterranean Sea's significance has decreased in contemporary circumstances, particularly since the expeditious development of air force

\footnotetext{
* MA student in Quds Studies, Social Sciences University of Ankara (ASBU), Turkey, azka.madihah@gmail.com.
} 
technology. For instance, Pape (1996) stated that the influence of air power in overseas conflicts is increasing as it projects force more rapidly and with less risk than land power and more formidably than naval power. Such arguments do not consider present and future settings, since the sea represents not only naval forces, coast guards, and civil-maritime industries, but also significant geographical, geopolitical, geostrategic, geoeconomic, and geocultural aspects. In particular, the sea-based capacity of a state can determine or influence events, currents, and developments both at sea and on land (Iliopoulos, 2009). The sea influences national strategic and political cultures, economies, and foreign policies, which has been shown by the shifting paradigm in geopolitics of power at sea to power coming from the sea. It corresponds with the argument by Marroni (2013) that states with control over ocean space gather national prestige, regional aspirations, and strategic access to natural resources.

Of the seas located near Bayt al-Maqdis, El-Awaisi (2018) has argued that the Mediterranean Sea is the most important, taking on the role of regional power compared to the other two seas, as it is located on all three circles inside the Barakah Circle Theory of Bayt al-Maqdis (Figure 2). The Mediterranean also has geopolitical advantages, such as its population, historical background, and resources. The population of the Mediterranean Sea's coastal countries increases significantly every year (D'Aponte, 2014) and is historically related to various civilisations, including the Byzantine and Ottoman Empires. The Mediterranean Sea also provides abundant food and energy resources. According to a recent biodiversity review by Coll et al. (2010), the number of macroscopic living species presently inventoried in this sea is estimated at about 13,200 species. This is a high figure, considering that the Mediterranean represents less than $0.8 \%$ of the world's overall ocean area, while representing roughly $5 \%$ of all known recent marine species (Templado, 2014), thereby proving its position as a vital source of food for population. The sea's coastal countries depend on seaborne trade for energy, food, and other commodities, and their needs will be accentuated in decades to come (Andritsos, 2011).

Despite the substantial role of the Mediterranean Sea in the geopolitics of the Bayt al-Maqdis and countries around it, the literature on this subject is limited. This topic requires further exploration since this geopolitical perspective could influence current and future national foreign policies. The most recognised international geopolitical theories have originated from the Western world and its colonialisation ambitions. The Mediterranean Sea, being the first colonised sea in the world (Borutta, 2012), may therefore be seen in light of the geopolitical perspectives that applied at the time of colonisation. However, Western geopolitical perspectives cannot be unreservedly accepted and applied by Muslims, who require an Islamic standpoint for understanding national, regional, and international contexts. Since the Barakah of Bayt al-Maqdis is intended for the universe, as was stated in Quran 21:71, it can therefore be seen that this region has essential international geopolitical value, which can be used to explain the global 
situation that includes cases occurring in the Mediterranean Sea. The Barakah of Bayt al-Maqdis is the foundation of a new geopolitical theory coined by Abd alFattah el-Awaisi: the Barakah Circle Theory of Bayt al-Maqdis (El-Awaisi, 2005). This theory explains that the Barakah of the Bayt al-Maqdis region grows and expands, encompassing the rest of the globe. El-Awaisi (2018) concluded that this region holds the direction towards world peace or conflict; if security and peace are established in Bayt al-Maqdis, then other regions will also experience sustainable security and peace.

The Barakah Circle Theory of Bayt al-Maqdis has three circles surrounding Bayt al-Maqdis with the first circle encompassing its geographical location and boundaries. The second circle includes Egypt, Historical Syria, and Cyprus while the third circle consists of Hijaz land, Iraq, Turkey, and Cyprus as well as parts of Kuwait, Libya, Sudan, and Iran (El-Awaisi, 2007). As the Mediterranean Sea is located in all of these circles, this paper will explore the significance of the Mediterranean Sea based on El-Awaisi (2005)'s geopolitical viewpoint. This paper will also examine some of the international events related to the Mediterranean Sea using the Barakah Circle Theory of Bayt al-Maqdis as the tool of analysis. This analysis will highlight the necessities to urgently define a strategic plan to liberate Bayt al-Maqdis from the perspective of the surrounding sea.

\section{THEORETICAL FRAMEWORK}

The most prominent geopolitical theory regarding sea power was devised by Alfred T. Mahan in 1949, who argued that sea power was a vital aspect for state prosperity, especially for the advance of its military and economy. Mahan wrote that "the history of sea power is largely, though by no means solely, a narrative of contests between nations, of mutual rivalries, of violence frequently culminating in war." Mahan also argued that there were six elements of sea power: geographical location (proximity to the sea), physical conformation (access to the sea through rivers, lakes, harbours, and ports), physical coastline layout, national population, national character (and attitude toward commerce and trade), and its governmental character (including its military relationship). The Mediterranean Sea, as the researcher argues, has all of these sea power elements and therefore, more attention should be put forward by Muslim countries to this sea.

Even though the geopolitical elements that determine the significance of a geographical unit from Mahan's point of view differ slightly from El-Awaisi's perspective, it still places emphasis on the significance of the sea for the world. El-Awaisi (2007) emphasised that geopolitical significance is defined by strategic location, population, resources, and historical background. This paper will use ElAwaisi's viewpoint as it corresponds to contemporary geopolitical circumstances, in comparison to Mahan's (1949) theory which uses a military stance as its foundation. Apart from using the Barakah Circle Theory of Bayt al-Maqdis to analyse current Mediterranean Sea events, this paper will also use Corbett's 
(1988) approach, which states that the true purpose of sea power is not so much what happens at sea, but how such action influences land-based events and outcomes.

As the Barakah Circle Theory of Bayt al-Maqdis is derived from Quran 17:1, this paper will also discuss Quranic verses that mention the sea to explore the sea's significance from an additional aspect. The further exploration of the sea's significance aligns with Djamil's (2012) terminology of "Oceanic Verse" and linguistic analysis of Quranic verses about the sea. This theory and framework will guide the investigation of the current situation of Mediterranean Sea, including its opportunity and threat in the future.

\section{THE MEDITERRANEAN SEA IN THE BARAKAH CIRCLE OF BAYT AL-MAQDIS}

El-Awaisi (2007) has highlighted the most comprehensive of Quranic terminologies: the land of "Barakah", which encompasses Bayt al-Maqdis virtues. Bayt al-Maqdis is mentioned as the land of the Barakah five times in the Quran. Barakah, as El-Awaisi (2007) explained, moves in circles around the Al-Aqsa Mosque and then reaches the globe, but not at the same scale. It diminishes gradually as one moves further from the mosque. This concept of Barakah is the foundation of our proposed geopolitical theory and can be manifested as physical and spiritual Barakah (El-Awaisi, 2007).

Determining whether the manifestation of Barakah is also bestowed upon the sea, especially the Mediterranean Sea, will provide insight as to the significance of that sea in this geopolitical theory. El-Awaisi (2007) explained that Barakah can be bestowed on objects, such as water, as confirmed by Quran surah Qaf, verse 9, "And We sent down from the sky water that is Mubarak and We made gardens grow by it and grown for harvesting". The Barakah of sky water or rain cannot be discussed without considering the sea as the primary source of rain in the water cycle, since most evaporated water comes from the sea. According to Djamil (2012), bahara (the root word of "ocean" and "sea") occurs 42 times in the Quran. This root word has heteronyms, such as ocean, sea, great river, great expanse of water, and a generous person or great knowledge. Djamil (2012) coined the term "Oceanic Verses" for these verses, highlighting that there should be specific research on this as $72 \%$ of the earth is covered by ocean.

According to these Quranic verses, as well as scientific facts, the ocean and sea are the origins of water and the source of life. Therefore, besides Bayt alMaqdis manifesting as the land of Barakah, the Mediterranean Sea may be considered as possessing another type of Barakah manifestation within its waters. Other seas, such as the Red and Black Seas that surround Bayt al-Maqdis, might also manifest Barakah, although further research on this point might be needed. According to the Barakah Circle Theory, the Mediterranean Sea has the highest level of Barakah radiation since it is located in the three circles of the theory. 
The Mediterranean Sea enables us to distinguish between al-Sham and the land of Barakah. El-Awaisi (2007) explained that over half of Barakah's land lies outside of al-Sham, placing it in the desert, parts of Egypt, or the Mediterranean. Specifically, the geographical boundaries of Bayt al-Maqdis are the River Jordan in the West, Jenin in the North, the Mediterranean Sea in the West, and Zoar in the South.

\section{THE SIGNIFICANCE OF THE MEDITERRANEAN SEA}

The name of the Mediterranean Sea itself derives from the Latin word Mediterraneus, which can be translated as "inland" or the "middle place between the land". The Romans appropriately thought of it as the mare nostrum, "our sea". From the beginning of recorded Western history, it has functioned as a sort of global commons in a relatively confined space, providing a path for trade, an accessible source of protein, a field of transport, a ready battlefield, and a natural barrier (Stavridis, 2018). The Mediterranean Sea is also famous as a sea with many names, such the Akdeniz (the White Sea) for the Turkish, Yam Gadol (the Great Sea) for Jewish people, Mittelmeer (the Middle Sea) for Germany, and the doubtfully-named "Great Green" of the ancient Egyptians (Abulafia, 2011). ElAwaisi (2007) mentioned that the Mediterranean coast was called, the coast of alQuds by Al-Dhahabi while Al-Maqdisi sometimes refers to it as the Roman Sea.

The many names of the Mediterranean Sea indicate the involvement of this sea throughout civilised history, granting it the significance of a rich historical background in geopolitical perception. Other geopolitical elements, explained by El-Awaisi (2018), highlight how every nation inside the Barakah Circle Theory is geopolitically significant due to its strategic location, considerable population, historical background, or plentiful natural resources.

Since the Mediterranean is strategically located between three continents (Asia, Europe, and Africa), the Mediterranean Sea has a significant geopolitical advantage. Moreover, the Barakah Circle Theory indicates that as given areas approach Bayt al-Maqdis (the center of Barakah), the effects of Barakah are perceived as more significant. As the Mediterranean Sea expands from the first circle to the third circle, it is the regional sea power in the same way that Egypt is the regional power (being located in both the second and third circles).

The Mediterranean Sea region, as the largest of the semi-enclosed European seas, is home to around 480 million people living across three continents (Figure 3). It remains one of the world's busiest shipping routes with about one-third of the world's total merchant shipping crossing the sea each year. Approximately one-third of the Mediterranean population is concentrated in its coastal regions with roughly 250 million people (or $55 \%$ of the total population) residing in coastal hydrological basins (UNEP MAP, 2009). These people are sustained mostly by food from the sea. 
The Mediterranean Sea also has considerable potential for energy resources, such as oil and gas. The latest oil and gas discoveries in the sea have attracted international interest. Nopens (2013) noted that if such development is not well managed, it could further destabilise the region. Nopens argued that major powers, including the US, Israel, the EU (especially the UK, France, Greece, and Cyprus), Russia, and Turkey were constantly competing for the redistribution of Eastern Mediterranean power regarding recently discovered hydrocarbon resources. For EU countries, these new resources could free Europe from overdependence on Russian gas. Meanwhile, Russia's energy policy has been aimed at blocking any alternative to its control over Europe's gas supplies. This involves an attempt to monopolise gas infrastructure from the Caspian Sea and Central Asia to Europe, which included exploiting Eastern Mediterranean energy resources.

In 2018, Turkey started drilling for oil and gas in the Mediterranean (Reuters, 2018), thereby affecting Turkey's position in the world's energy supply chain. This came after previous attempts aimed at becoming an energy hub supplying gas and oil to Europe, involving the use of geographic positioning between multiple energy suppliers and the European market. The US, by contrast, has viewed the Mediterranean Sea as a highway for the projection of US power deep into the heart of Eurasia and Africa (Lloyd, 2009). Such competition for energy and power, along with the Arab Spring events, have shifted the geopolitical position of the Mediterranean from its naval power to its energy, economic, and political power.

The Mediterranean Sea's history chronicles humanity's geopolitical journey upon the seas as the first sea in which war was declared (Stavridis, 2018). Al-Tel (2003) argued that Alqama ibn Hakim's stationing of soldiers at al-Ramla, which is close to the Mediterranean coast, could be understood in the context of the coast still being under attack from the Byzantine military fleet which continued over a long period of time. In 1870, the Ottoman Empire held 32 ports on the Mediterranean Sea, another 11 on the Black Sea, and 5 more upon the Red Sea among its 70 ports (Urgan, 2015). Reitzel (1948) stated that at least 15 sovereign states are directly concerned with the Mediterranean Sea (including Europe, Great Britain, the US, and the Soviet Union) with differing commercial, political, and security interests. The sea currently remains an object of international interest with oil and gas drilling, pipeline projects, naval highways, refugee migration, the occupation of the Gaza coastline, and the attack of the Freedom Flotilla among its interests.

Consistent with El-Awaisi's theory that Bayt al-Maqdis and its surroundings are the centre of the world's peace and conflict, most events that have occurred in the Mediterranean Sea are located inside the three circles in the Barakah Circle Theory. For example, D'Aponte (2014) argued that a global view of the whole Mediterranean area required designating different sides (Figure 4) as follows: 


\section{North Corner:}

A) Stable areas (European countries): Spain, Italy, France, Greece, Bulgaria, Romania, Slovenia, and Croatia;

B) Areas in transition with moderate instability: Bosnia, Turkey, Serbia, Montenegro, and Albania; and

C) Unstable and critical areas: Ukraine, Georgia, Armenia, and Azerbaijan.

\section{South Corner:}

A) More occidental and stable areas: Morocco;

B) Areas transitioning to new political systems: Tunisia and Algeria; and

C) Politically and economically unstable countries: Libya and Egypt.

\section{East Corner:}

A) Unstable and critical areas: Sudan, Eritrea, Gabon, Ethiopia, and Somalia;

B) Unstable areas: Iraq and Iran; and

C) Critical areas with potential or actual conflicts: Palestine, Israel, Lebanon, and Syria.

The author argues that this instability in the coastal countries of the Eastern Mediterranean Sea as stated by D'Aponte might be related to the Barakah Circle Theory of Bayt al-Maqdis. In this theory, Bayt al-Maqdis and its surrounding area are the centre of the world's peace and conflict. Thus, according to this theory, peace will be established only if these areas achieve peace and stability, as proven during the era of Umar Ibn al-Khattab and Salahuddin Al-Ayyubi (El-Awaisi, 2012).

\section{THE OCCUPATION OF THE MEDITERRANEAN SEA IN BAYT AL-MAQDIS}

According to the Barakah Circle Theory, the Eastern part of the Muslim and Arab world is the geographical location that should be ruled by Muslim leaders, encompassing land, sea, natural resources, energy, and culture. Knowledge of the seas, especially the Mediterranean Sea, is necessary to control them. Notwithstanding the consequences of El-Awaisi's proposition, it is commonly known that Muslims do not have total control of the Mediterranean Sea at present, which might be correlated with the entwined military, political, and economic interests from coastal countries and superpowers. When Israel declared itself a state, it claimed Tel Aviv and Jerusalem City as de facto joint capitals from May to December of 1948. A possible rationale for this decision may have been to do with strengthening the new nation's control over land, sea, and air in the Bayt al-Maqdis region, with Tel Aviv/Jaffa within its boundaries. It is also the nearest city to the Mediterranean Sea inside the first circle of the Barakah Circle Theory, granting Israel better access to economic, tourism, energy, food resources, industry, transportation, naval security and the sea. As Andritsos (2011) stated, Mediterranean coasts are densely populated, causing fierce competition for the coastal zone and accentuating environmental, safety, and security issues. Indeed, ports and terminals are often close to densely inhabited areas and are integral parts of coastal towns, making their interaction with the regional social tissue and territory a key parameter to planned development.

Another case that may be used to illustrate how the Mediterranean Sea is closely tied to regional power among coastal countries is the prohibition placed 
on Palestinian fishers to sail no more than six nautical miles into the sea off Israel. Previously, the Israeli-imposed permitted fishing zone for Palestinian fishers was nine nautical miles. After a long demonstration on the Gaza border, Israeli Defence Minister Avigdor Lieberman ordered the permissible zone for Palestinian fishers off the coast of Gaza to be scaled down to six nautical miles (Forrest, 2018). Since Gaza is located on the second circle of the Barakah Circle of Bayt al-Maqdis, it is essential to include its events to develop a better geopolitical understanding of this area. These events appear to support the assumption that occupation or colonialisation occurs at sea as well as on land. Israel also utilises $85 \%$ of the water from Palestinian water resources, violating International Water Law. Palestinian rights of access to the Mediterranean and the Dead Sea for fishing, port development, tourism, natural resource optimisation, and shipping have also been violated by Israeli occupation (Sabbah \& Isaac, 1995). Thus, liberating Bayt al-Maqdis should include the liberation of the sea.

A similar case can also be made relating to an attack on the Freedom Flotilla that occurred on May 31, 2010. Israeli soldiers raided a humanitarian flotilla, killing several passengers. The UN Secretary-General's Panel of Inquiry reported that a naval blockade was imposed as a legitimate security measure to prevent weapons from entering Gaza by sea and its implementation complied with international law (UN Report, 2011). However, evidence presented by convoy organisers showed that the flotilla had asked all participants to sign a declaration before embarking on the journey that they would not engage in any action that would in any way contravene the purely humanitarian mission of the flotilla $(\mathrm{IHH}, 2012)$. Israeli naval special forces intercepted the convoy in international waters about 73 nautical miles from the coastline of Bayt al-Maqdis, inside the second circle of the Barakah Circle of Bayt al-Maqdis (Figure 5).

This incident, according to the Barakah Circle Theory, could be attributed to an occupier of Bayt al-Maqdis controlling the Mediterranean Sea. The incident correlates with El-Awaisi's (2018) argument that Egypt and Syria, located on the second circle, will always be the target of occupation, destruction, and control from occupiers or superpowers with interest in Bayt al-Maqdis. This incident has had significant diplomatic repercussions, most prominently for Israel's relationship with Turkey and also throughout the Middle East (Steinberg, 2010). This proves Corbett's theory that the influence of sea events on land events exceeds the direct influence of the actions themselves. Despite the severe outcome of this incident, Israel has been trying to prevent international legal action toward this attack by maintaining pressure in several ways, including upon the US government $(\mathrm{IHH}, 2012)$. Voting results in the UN Human Rights Council show that several EU countries abstained during the voting session on the report while the US registered the only negative vote. This case demonstrates a concept within the theory of Barakah Circle of Bayt al-Maqdis: justice that respects human dignity and human rights should be applied first before establishing peace (El-Awaisi, 2018). 


\section{CONCLUSION}

This study illustrated the key role that the Mediterranean Sea plays in the geopolitical balance between coastal states and superpowers. It is related to the fact that the sea became the strategic location of interaction between different communities in the world. It also becomes the subject of disputes and conflicts, which have shifted from naval, military, and international trade issues to energy issues (such as gas and oil). Nonetheless, this sea remains the sea power of the region.

Since the Mediterranean Sea is located inside the Barakah Circle Theory of Bayt al-Maqdis, this theory suggests that all nations must notice the magnitude of the sea, as well as the land and the air, to protect their sovereignty. El-Awaisi, as the founder of this theory, highlighted Cyprus as a strategic location in the Mediterranean Sea that should be protected. He argued that the liberation of Islamicjerusalem would not occur until Muslims realise the unification of Egypt and Syria in the second circle. For that reason, Egypt, Syria, and other coastal Mediterranean countries inside the Barakah Circle of Bayt al-Maqdis require full sovereignty over their coasts and ocean zones to defend themselves from foreign invasion. Based on this geopolitical theory, all conflicts in the region will end if peace is established in Bayt al-Maqdis, leading to an end of global conflicts.

As a conclusion, this study suggests that these Muslim countries, and particularly Turkey as the most influential state in the Mediterranean Sea's coastal area and in the third circle of the Barakah Circle theory, should be aware of the potential, threat, and Barakah associated with this sea to establish peace in Bayt al-Maqdis. Regarding the occupation and illegal prohibition set by Israel, Muslim countries also should take legal action and prevent further acts of naval oppression. This is because the occupation of the sea is as hazardous as the occupation of land, as has been experienced by the population in Bayt al-Maqdis since 1917 . 


\section{BIBLIOGRAPHY}

Aydın, M. (2004). Turkish Foreign Policy Framework and Analysis. Ankara: Sam Papers.

Abulafia, David. (2011). The Great Sea: A Human History of the Mediterranean. London, England: Penguin Books.

Andritsos, Fivos. (2011). Oil \& Gas in The Mediterranean Risks \& Opportunities. Retrieved from: https://www.researchgate.net/publication/258484828_OIL_GAS_IN _THE_MEDITERRANEAN_RISKS_OPPORTUNITIES

Borutta, Manuel. (2012). A Colonial Sea: the Mediterranean, 1798-1956. European Review of History: Revue européenne d'histoire, 19:1,1-13. Retrieved from: https://www.tandfonline.com/doi/abs/10.1080/13507486.2012.643609

Coll M, Piroddi C, Steenbeek J, Kaschner K, Ben Rais Lasram F, et al. (2010). The Biodiversity of the Mediterranean Sea: Estimates, Patterns, and Threats. Journal of PLOS ONE 5(8): e11842. Retrieved from https://doi.org/10.1371/journal.pone.0011842.

Corbett, Julian. (1988). Some Principles of Maritime Strategy. Annapolis: Naval Institute Press.

D'Aponte, Tullio. (2014). A Geopolitical Overview on the Mediterranean Sea: The Approach of the Euro-Med Policy Towards the Countries of the Southern Front (From Morocco to Egypt). Rivista Italiana di Economia Demografia e Statistica Volume LXVIII n.2.

Djamil, Agus S. (2012). Oceanic Verses of the Quran: Their Semantics, Ontology and Categorization. Retrieved from https://www.academia.edu/9703329/Oceanic_Verses _of_the_Quran_Their_Semantics_Ontology_and_Categorization

Djamil, Agus S. (2012). The Qur'an Revelations on Marine Knowledge. Retrieved from https://www.academia.edu/9704433/QURAN_ON_MARINE_KNOWLEDGE

El-Awaisi, Abd al-Fattah. (2007). Introducing Islamicjerusalem. Dundee, United Kingdom: AlMaktoum Institute Academic Press.

El-Awaisi, Abd al-Fattah. (2018). BMS501: Introducing Bayt al-Maqdis Studies Course. Social Sciences University of Ankara, Ankara, Turkey.

El-Awaisi, Abd al-Fattah. (2018). Towards Building New Image for International Relations: Bayt al-Maqdis Islamicjerusalem Theories and Models for Interpreting and Directing the Current Events and Making the Future History. Unpublished manuscript.

El-Awaisi, Khalid. (2007). Mapping Islamicjerusalem. Dundee, United Kingdom: Al-Maktoum Institute Academic Press.

Forrest, Adam. (2018). Israel Reduces Palestinians' Permitted Fishing Zone by a Third. Retrieved from: www.independent.co.uk/news/world/middle-east/israel-gazapalestinian-fishing-zone-protests-avigdor-lieberman-human-rights-a8572051.html.

Iliopoulos, Ilias. (2009). 5 Strategy and Geopolitics of Sea Power throughout History. Baltic Security \& Defence Review Volume 11, Issue 2. Retrieved from http://www.baltdefcol.org/files/files/BSDR/BSDR_11_2.pdf

IHH Research and Publications. (2012). Mavi Marmara - Gaza Freedom Flotilla (E-book version). Istanbul, Turkey: IHH Kitap. Retrieved from: https://www.ihh.org.tr/public/publish/o/79/mavi-marmara-freedom-flotilla.pdf

IHH Humanitarian Relief Foundation. (2012). The Mavi Marmara Case Legal Actions Taken Against the Israeli Attack on the Gaza Freedom Flotilla on 31.05.2010. Retrieved from: https://www.ihh.org.tr/public/publish/o/126/the-mavi-marmara-case.pdf

Gardner, Lloyd C. (2009). Three Kings: The Rise of an American Empire in the Middle East after World War II. New York, USA: The New Press.

Mahan, A. T. (1949). The Influence of Sea Power Upon History, 1660-1783. Boston, UK: Little, Brown. 
Marroni, Etiene V. (2013). Geopolitical Strategy for the Territorialism of Oceans and Seas. International Journal of Geosciences, vol 4, 1051-1054. Retrieved from http://dx.doi.org/10.4236/ijg.2013.47098

Montgomery. (2010). Gaza Flotilla Raid Map. Retrieved from https://en.wikipedia.org/wiki/Gaza_flotilla_raid

Nopens, Patrick. (2013). Geopolitical Shifts in the Eastern Mediterranean. Security Policy Brief No. 43. Retrieved from https://core.ac.uk/download/pdf/148867415.pdf

Pape, Robert A. (1996). Bombing to Win: Air Power and Coercion in War. New York, USA: Cornell University Press.

Reitzel, William. (1948). Mediterranean: Its Role in America's Foreign Policy (E-book version). Michigan, USA: Harcourt Brace.

Sabbah, W. \& Isaac, J. (1995). Towards a Palestinian Water Policy. Betlehem, West Bank: Applied Research Institute.

Stavridis, James. (2017). Sea Power: The History and Geopolitics of the World's Oceans. New York, USA: Penguin Press.

Steinberg, P. E. (2011), The Deepwater Horizon, the Mavi Marmara, and the Dynamic Zonation of Ocean Space. The Geographical Journal, 177: 12-16. Retrieved from https://doi.org/10.1111/j.1475-4959.2010.00383.x

Templado, José. (2014). The Mediterranean Sea: Its History and Present Challenges. London, UK: Springer.

Trochim, William M. (2016). Research Methods: The Essential Knowledge Base. Hampshire, UK: Cengage Learning.

UNEP MAP. (2009). UNEP/MAP-Plan Bleu: State of the Environment and Development in the Mediterranean. Athens, Greece: United Nations Environment Programme/Mediterranean Action Plan (UNEP/MAP).

United Nations, Report of the Secretary-General's Panel of Inquiry on the 31 May 2010 Flotilla Incident. September 2011. Retrieved from http://www.un.org/News/dh/infocus/middle_east/Gaza_Flotilla_Panel_Report.pdf 


\section{APPENDICES}

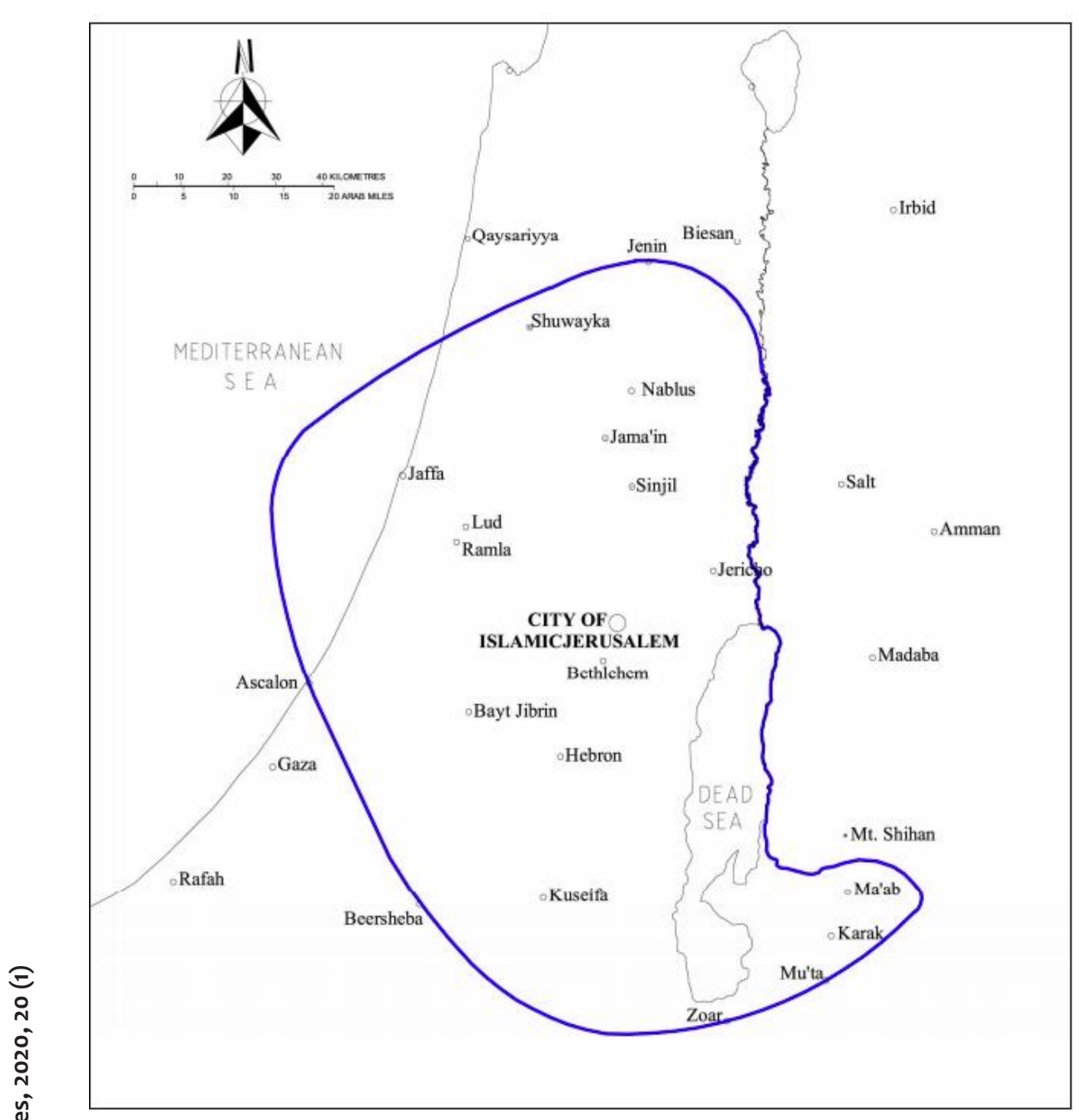

Figure 1: Boundaries of the Bayt al-Maqdis Region, Khalid El-Awaisi (2007). 


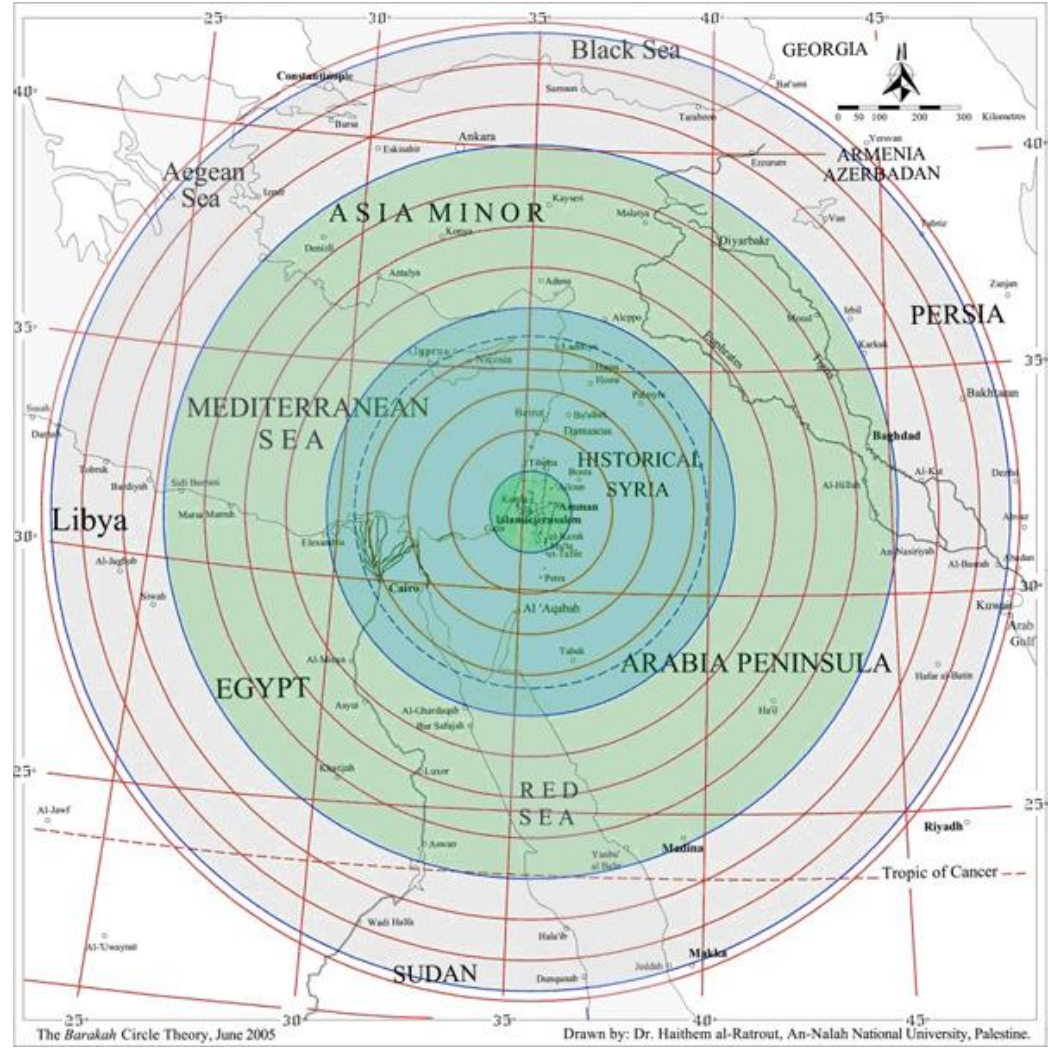

Figure 2: El-Awaisi's Barakah Circle Theory of Bayt al-Maqdis, El-Awaisi (2005).

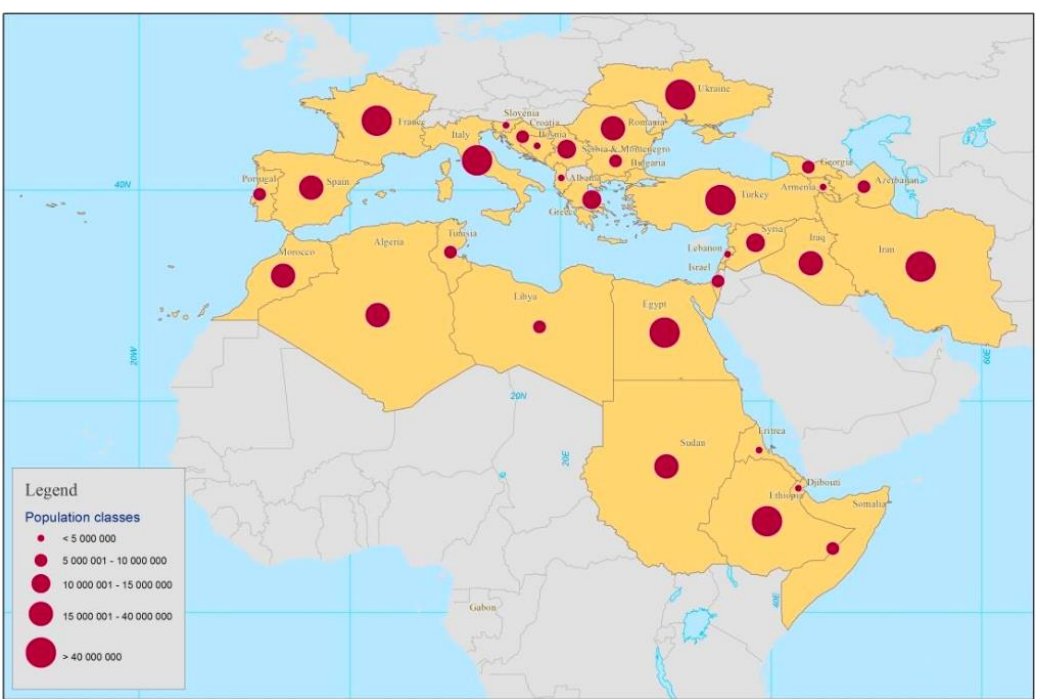

Figure 3: Populations of Mediterranean Coastal Countries (Extended Mediterranean), Tullio D’Aponte (2014). 


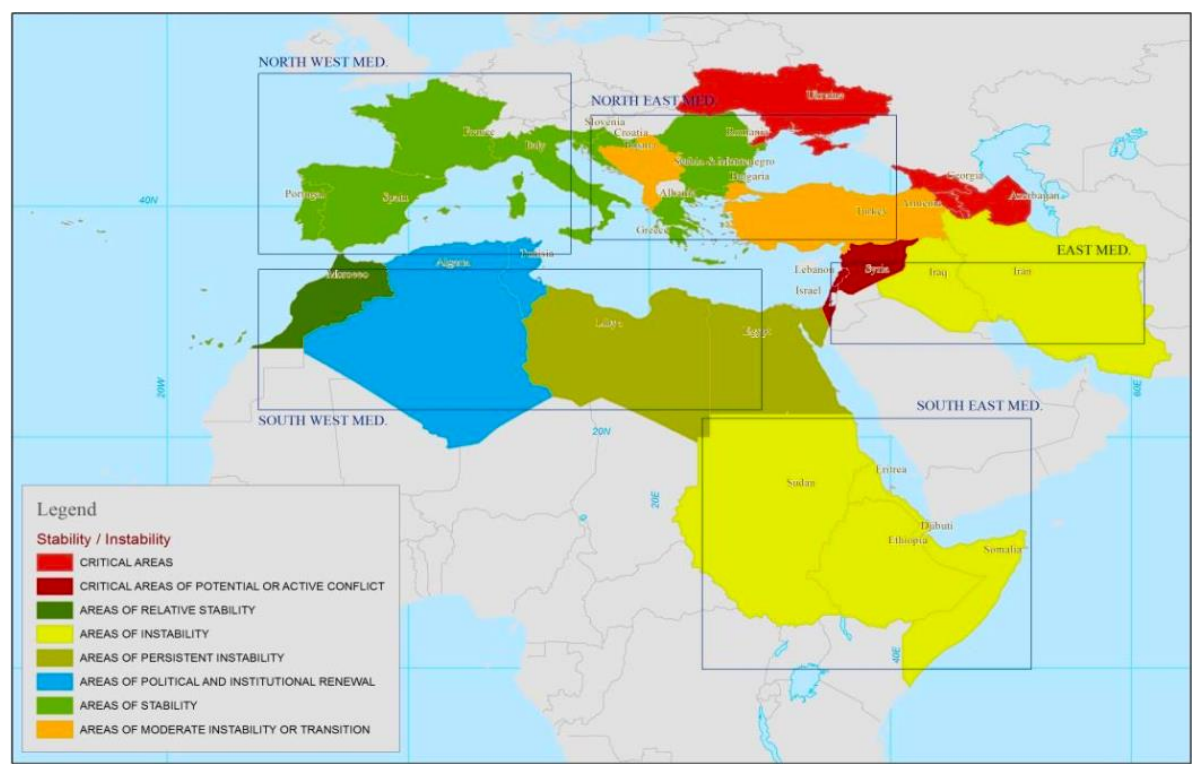

Figure 4: Critical Areas of Political Instability in the Extended Mediterranean, Tullio D'Aponte (2014).

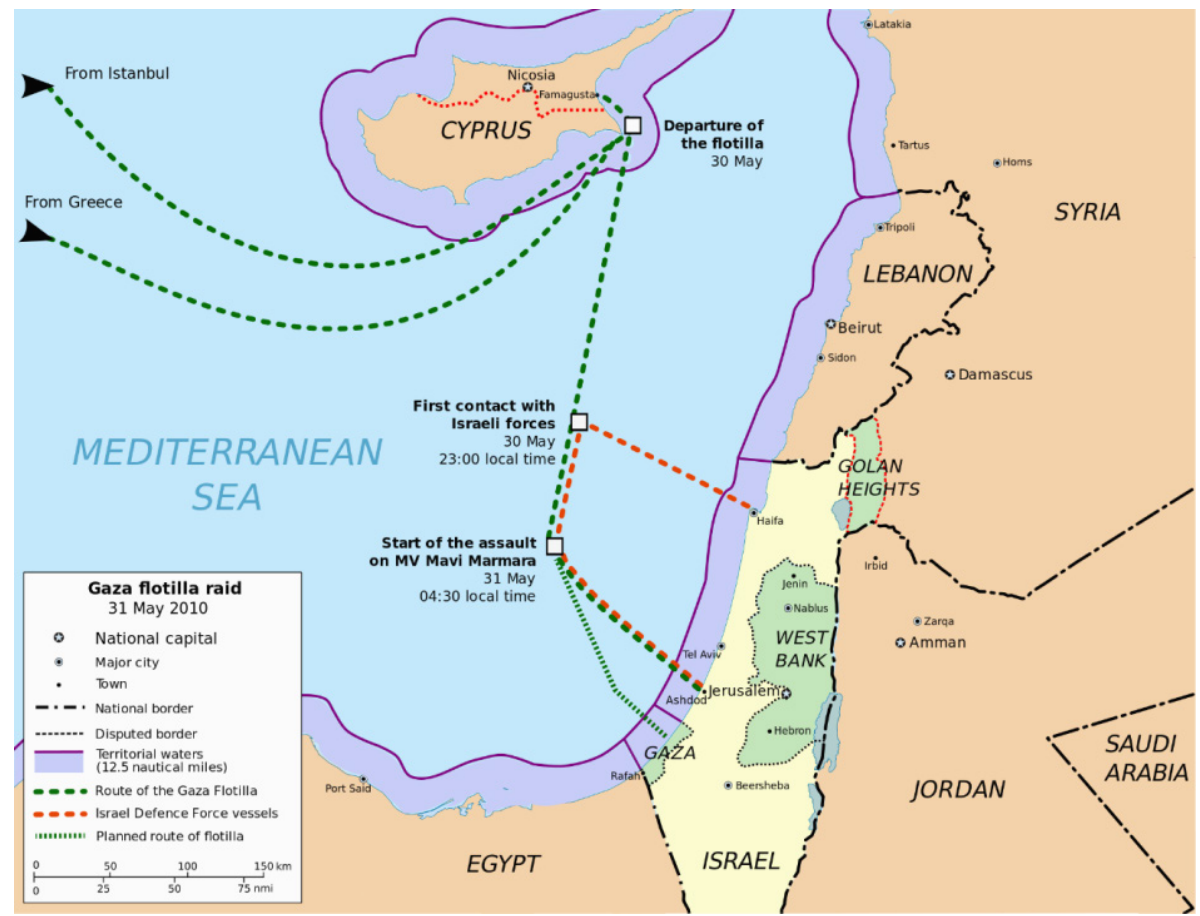

Figure 5: The Location of Israeli Attack on the Freedom Flotilla, Montgomery (2010). Note: The label of Israel on this map is due to the limitation of research published on this issue and does not mean recognising such a state in the region of Bayt al-Maqdis. 